\title{
Public Research, Open Science and Innovation: Creating the Path for Sustainable Resource-Led Industrialisation in Malaysia
}

\author{
Rokiah Alavi and Ida Madieha Abdul Ghani Azmi
}

\begin{abstract}
This paper intends to demonstrate the importance of innovation in primary resources by the government research institutes (GRIs) and the practice of open science in creating the path for resource-led and knowledge-intensive industrialisation in Malaysia. The core argument here is that a successful resource-led industrialisation lies on the technological advancement in the primary resources developed by GRIs. The focus of this study is on rubber industry and research undertaken by the Malaysian Rubber Board (MRB). Research methods used were interviews and secondary data search. It is found that $R \& D$ undertaken by rubber research centres and their open science practice have sustained Malaysia's quest to be the leading producer and exporter of natural rubber and rubber based products.
\end{abstract}

Index Terms-Industrialisation, open science, innovation, public research, rubber.

\section{INTRODUCTION}

There is large body of literature that has documented the positive impact of public-funded research technologies on industrial innovation [1]. Most of the agriculture technology development takes place in government research institutes (GRIs) that are established to support specific key national economic areas [2]. These institutes usually have a clearly targeted user industry and their research emphasis largely oriented towards problem-solving and developing technologies that are tailor-made to specific need of a particular industry.

In Malaysia, public funded research, especially the GRIs, has focused on agricultural sciences [3]. Total amount of R\&D fund disbursed for public research institutions and universities increased phenomenally from RM148.3 billion in current prices in 1996 to RM2159.7 billion in 2009. About one-third of public research funding goes into primary commodity research institutes such as the Malaysian Palm Oil Board (MPOB), Malaysian Rubber Board (MRB), Malaysian Cocoa Board (MCB) and Forest Research Institutes Malaysia (FRIM) [4].As a consequent of the expansion in $R \& D$ spending, patent applications by public research institutions rose impressively from 2 to 734 patents in 1987 and 2010 respectively. In terms of percentage, this represents an increase from $4 \%$ to $59 \%$ of total local patent applications.

Despite the impressive increase in the $R \& D$ expenditure and patenting activities by public research institutions and universities, their contribution to industrial development and creating domestic capabilities has been limited. The main

Manuscript received March 15, 2013; revised May 17, 2013. This research was funded by the International Islamic University Malaysia.

Rokiah Alavi and Ida Madieha Abdul Ghani Azmi are with the International Islamic University Malaysia (e-mail: rokiahalavi@gmail.com) reasons that have inhibited private firms from collaborating with GRIs are lack of relevance between research undertaken by public sector and the need of the industry, low level of awareness on availability of support facilities and insufficient promotion on such services and tedious paperwork and time consuming bureaucratical procedures. Nevertheless, in the Malaysian case, there has been close and strong industrial linkages between commodity-based research institutes and industry. The Malaysian Rubber Board (MRB) and Rubber Research Institute of Malaysia (RRIM) for example, have had enormous impact on industrial development of domestic rubber-based industry. Breakthroughs in breeding new clones (varieties) of rubber for instance have benefited thousands of producers in Malaysia, and have contributed to the impressive growth of rubber industry and strengthened international competitiveness of rubber-based and rubber-wood industries.

The motivation for this study arise from the concern that agricultural and primary commodity technological advancement which in the past has benefitted strong public sector support and funding is now facing an uncertain future. There are two issues of concern. Firstly, GRIs are increasingly being expected to be financially independent, thus they are compelled to adopt market mechanisms to survive, resorting to license their technologies as well as commercialising their research outputs to reap returns to R\&D investments. Secondly, public research institutes are now already deep into claiming propriety rights of their research findings. In the past, public funded scientific outputs are commonly left to public knowledge [5], [6] and therefore have benefitted wider spectrum of end-users. These developments could hinder technology transfer, limit dissemination of knowledge, constraint backward and forward linkages with other industrial sector, and hence, affecting the growth and development of resource-led industrialisation.

The focus of this paper will be on the rubber industry. It sets to show how R\&D and innovation in primary commodity by GRIs and free access to their research outcomes has contributed to the success of the natural rubber and rubber based industries in Malaysia. This paper has two sections. The first section discusses the research and patenting trends by Malaysian GRIs. The second section analyses how public research and open science practice have contributed to the development and success of Malaysian rubber industry.

\section{RESEARCH AND PATENTING ACTIVITIES IN GRIS}

As mentioned earlier, total amount of R\&D fund disbursed for GRIs and institute of higher learning (IHLs) increased phenomenally from RM148.3 billion in current prices in 1996 to RM2159.7 billion in 2009. This increase is mainly 
contributed by Malaysian government's policy shift since mid-1980s that placed greater emphasis on $R \& D$ in its five-year economic plans. The government introduced the Intensification of Research in Priority Areas (IRPA) grant to fund research activities in IHLs and GRIs in 1986 and since then various types of research funds were disbursed to support research and development in the public institutions.

The share of R\&D expenditure by IHLs and GRIs in total national R\&D expenditure is around 30\%. Nevertheless, the funding trend shows greater emphasis has been given to IHLs to conduct R\&D as compared to the GRIs since 2004 onwards (see Fig. 1).The share of R\&D expenditure by GRIs fell from $19.8 \%$ in 1996 to $6.4 \%$ in 2009 . On the other hand, $\mathrm{R} \& \mathrm{D}$ expenditure by IHLs experience steady increase over the years, climbing from $7.3 \%$ in 1996 to $14.4 \%$ and $23.7 \%$ in 2009.

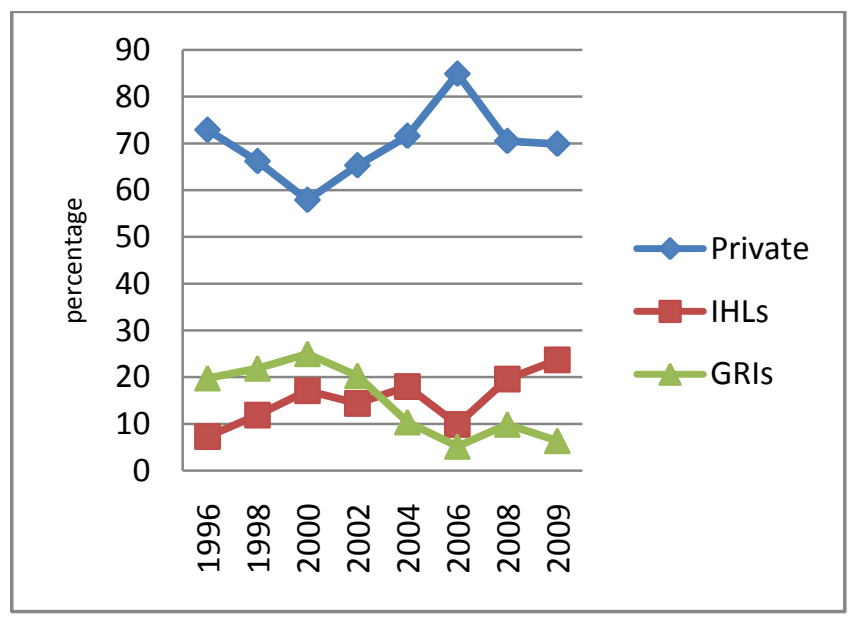

Fig. 1. R\&D expenditure by Sector, 1996-2009(\%).

Source: Based on Data obtained from MASTIC Website (Accessed on 27 February 2013).

Patent applications by universities and public research institutes recorded significant increase in the last decade. It rose from an average of $4 \%$ of total local patent applications in 1987 to an average of $10 \%$ between 2001 and 2006. In 2010, the share was $58 \%$ (see Table I). This indicates that a large share of innovation activities in Malaysia took place in universities and government-funded agricultural research centres.

In 2006, Universiti Perdana Malaysia (UPM) was the top patent applicant among local universities with 134 patent applications, followed by Universiti Malaya (72), Universiti Teknologi Malaysia (53) and Universiti Teknologi MARA (50). Six of the top 15 patent applicants in that year comprise of IHLs; whilst 3 were GRIs.

TABLE I: LOCAL PATENT APPLICATION: INSTITUTE OF HIGHER LEARNING AND GOVERNMENT RESEARCH INSTITUTES IN MALAYSIA, 2005-2010

\begin{tabular}{l|c|c|c|c|c|c}
\hline & 2005 & 2006 & 2007 & 2008 & 2009 & 2010 \\
\hline IHLs & 81 & 94 & 165 & 272 & 574 & 533 \\
\hline GRIs & 28 & 30 & 87 & 141 & 183 & 201 \\
\hline Total IPT and RI & 109 & 124 & 252 & 413 & 757 & 734 \\
\hline$\%$ of IHLs & 16 & 18 & 25 & 31 & 47 & 42 \\
\hline$\%$ of GRIs of IHLs and & 5 & 6 & 13 & 16 & 15 & 16 \\
\hline $\begin{array}{l}\text { \%RIs } \\
\text { Total Local } \\
\text { Patent }\end{array}$ & 522 & 531 & 670 & 864 & 1234 & 1275 \\
\hline Source: MyIPO & & & & & & \\
\hline
\end{tabular}

here are about 40 agencies that are involved in agricultural research in Malaysia [7]. However, only three research institutes are directly involved in primary commodity research namely Malaysian Rubber Board (MRB), Malaysian Palm Oil Board (MPOB) and Malaysian Cocoa Board (MCB). The next section discusses the R\&D activities undertaken by the MRB and its link with the industries in Malaysia.

\section{PUBliC R\&D AND RUBBER INDUSTRY IN MALAYSIA}

Technological advancement in the plantation and processing of natural rubber industry and a significant number of technologies that are widely used in the world today has its origin from Malaysian research and development [8]. Intensification of rubber research in Malaysia created a pool of highly experienced and capable scientists on all aspects of NR and rubber products technology and rubber-wood furniture industry. Malaysia has produced versatile and higher quality raw materials from natural rubber research that are suitable for various manufacturing activities [9].

The Malaysian rubber sector did have an impressive technological advancement record. In the 1950s and 1960s, Malaysia was only known for its primary commodity exports particularly natural rubber. Today, Malaysia is the world's leading producer and exporter of natural rubber gloves, catheters and latex thread, supplying $60 \%$ of the world market for rubber gloves, $70 \%$ for catheters and $70 \%$ for latex thread. Malaysia's position as the leading producer of rubber gloves is expected to be further enhanced through inclusion of rubber sector as one of the 12 sectors in the National Key Economic Area (NKEA). These achievements are obviously are the spin-off effects of the effective research in the resource sector.

Rubber research in Malaysia began since the early $20^{\text {th }}$ century. Initial research initiatives were undertaken by private sectors such as Dunlop Plantations, Guthrie Plantations and Harrisons and Crossfield Plantations [3]. The first public research institute in Malaysia was the Rubber Research Institute of Malaysia (RRIM), established by the colonial Government in 1925 to cater to the needs of industries in Britain. This institute is now known as Malaysian Rubber Board (MRB). MRB is an agency under the Ministry of Plantation Industries and Commodities (KPPK) with the specific purpose to promote and develop the rubber industry of Malaysia [9]. Today, Malaysia is known to have the most comprehensive and advanced R\&D infrastructure facilities in the world in natural rubber [9].

RRIM was the first GRIs in Malaysia that has filed for patent protection. This was in 1934. Since then, the institute has patented 121 technologies (until 2010). Most of these patents involve upstream and midstream level products and technologies. Table II presents patent granted to GRIs involved in agricultural research. Patent data in the table shows that other GRIs that were established three to four decades later than MRB have far greater number of patent registrations than MRB. Between 2005 and 2010, MRB patented only 6 technologies, as compared to MPOB (98), FRIM (23) and MARDI (32). 
In fact, the number of patent owned is only a small fraction of total number of technologies that have been developed by MRB. This is because MRB practices open science principles where most of the research outputs are left in public domain. Their rationale is that since the R\&D fund are sourced from cess charges imposed on natural rubber exporters, the technologies developed by MRB should directly benefit the upstream and midstream sectors, and disseminated without any charges.

TABLE II: PATENTS GRANTED TO GRIS UNDERTAKING RESEARCH IN AGRICULTURAL SCIENCE AND PRIMARY COMMODITY, 2005-2010

\begin{tabular}{|c|c|c|c|c|c|c|c|}
\hline R\&D institutes & $\begin{array}{l}2 \\
0 \\
0 \\
5\end{array}$ & $\begin{array}{l}2 \\
0 \\
0 \\
6\end{array}$ & $\begin{array}{l}2 \\
0 \\
0 \\
7\end{array}$ & $\begin{array}{l}2 \\
0 \\
0 \\
8\end{array}$ & $\begin{array}{l}2 \\
0 \\
0 \\
9\end{array}$ & $\begin{array}{l}2 \\
0 \\
1 \\
0\end{array}$ & Total \\
\hline $\begin{array}{l}\text { Malaysian Palm Oil Board } \\
\text { (MPOB) }\end{array}$ & $\begin{array}{l}1 \\
9\end{array}$ & $\begin{array}{l}1 \\
0\end{array}$ & $\begin{array}{l}2 \\
1\end{array}$ & $\begin{array}{l}1 \\
0\end{array}$ & $\begin{array}{l}1 \\
9\end{array}$ & $\begin{array}{l}1 \\
9\end{array}$ & 98 \\
\hline $\begin{array}{l}\text { Forest Research Institute } \\
\text { Malaysia (FRIM) }\end{array}$ & 1 & 1 & 0 & 2 & 3 & $\begin{array}{l}1 \\
6\end{array}$ & 23 \\
\hline $\begin{array}{l}\text { Malaysia Agricultural Research } \\
\text { and Development Institute } \\
\text { (MARDI) }\end{array}$ & 2 & 8 & 4 & 7 & 4 & 7 & 32 \\
\hline $\begin{array}{l}\text { Malaysia Rubber Board } \\
\text { (MRB) }\end{array}$ & 1 & $\mathbf{0}$ & 1 & $\mathbf{0}$ & 2 & 2 & 6 \\
\hline Malaysian Cocoa Board (MCB) & 1 & 1 & 2 & 0 & 1 & 1 & 6 \\
\hline $\begin{array}{l}\text { Total Patent Applications by All } \\
\text { GRIs }\end{array}$ & $\begin{array}{l}3 \\
6\end{array}$ & $\begin{array}{l}3 \\
3\end{array}$ & $\begin{array}{l}1 \\
0 \\
9\end{array}$ & $\begin{array}{l}1 \\
4 \\
1\end{array}$ & $\begin{array}{l}1 \\
7 \\
3\end{array}$ & $\begin{array}{l}1 \\
9 \\
5\end{array}$ & 687 \\
\hline
\end{tabular}

Source: MyOPI (unpublished)

Table III shows that MRB's R\&D has been mainly on upstream and midstream technologies. MRB's research focuses on improvement and management of rubber plantation and processing with emphasis on agronomy, exploitation techniques, and integrated farming, agroforestry and laboratory automation techniques. Its key area of research activities includes:

- Latex harvesting technologies; which includes stimulation techniques such as ethephon based formulation, gaseous method, low intensity tapping system and mechanization in latex harvesting

- Management of soils and agronomic practices such as fertilizer recommendation of immature rubber; rhizobium compost,

- Rubber forest plantation

- Integrated farming.

Its first patent was on improvements relating to the treatment of rubber latex. Up to end of 1950s, a total of 14 patents were granted to this agency and the focus of its technology development has been on improvement in latex preparation and processing, management of soil and agronomy practices. The highest number of patents was granted in 1960 s and 1970 s, totalling 63 patents. Though the focus of research during this period remained the same, the institute advanced into technologies on methods and apparatus to be used by rubber planters and processers. In the 1980s, only 6 patents were registered by MRB. However, the number of patents increased gradually in 1990s and 2000s, where 14 and 24 patents were granted respectively.

\begin{tabular}{|c|c|c|}
\hline Years & $\begin{array}{l}\text { Number of } \\
\text { Patents } \\
\text { Granted }\end{array}$ & Focus of Technology Development \\
\hline $1934-1937$ & 6 & $\begin{array}{ll}\text { - } & \text { Improvement in Latex } \\
\text { Preparation and Processing } \\
\text { - } \\
\text { Management of Soil and } \\
\text { Agronomy Practices }\end{array}$ \\
\hline 1943 & 1 & $\begin{array}{l}\text { - Improvement in Latex } \\
\text { Processing }\end{array}$ \\
\hline $1952-1959$ & 7 & $\begin{array}{l}\text { - Management of Soil and } \\
\text { Agronomy Practices } \\
\text { Improvement in the manufacture } \\
\text { of rubber }\end{array}$ \\
\hline $1960-1968$ & 33 & $\begin{array}{ll}\text { - Improvement in Latex } \\
\text { Preparation and Processing } \\
\text { - } \quad \text { Management of Soil and } \\
\text { Agronomy Practices } \\
\text { - Improvements in the } \\
\text { manufacture of rubber } \\
\text { - } \quad \text { Rubber Product } \\
\text { - Method and Apparatus }\end{array}$ \\
\hline $1970-1979$ & 30 & $\begin{array}{ll}\text { - } & \text { Improvement in Latex } \\
\text { Preparation and Processing } \\
\text { Management of Soil and } \\
\text { Agronomy Practices } \\
\text { - } \quad \text { Improvements in the } \\
\text { manufacture of rubber } \\
\text { - } \quad \begin{array}{l}\text { Improvement in the manufacture } \\
\text { of rubber }\end{array} \\
\text { - } \\
\text { Rubber Product }\end{array}$ \\
\hline $1981-1989$ & 6 & $\begin{array}{ll}\text { - } & \text { Improvement in Latex } \\
\text { - } & \text { Preparation and Processing } \\
\text { - } & \text { Method and apparatus } \\
& \text { Rubber Product }\end{array}$ \\
\hline $1990-1999$ & 14 & $\begin{array}{ll}\text { - } & \text { Improvement in Latex } \\
\text { - } & \text { Preparation and Processing } \\
\text { - } & \text { Method and apparatus } \\
\end{array}$ \\
\hline $2000-2010$ & 24 & $\begin{array}{ll}\text { - } & \text { Improvement in Latex } \\
\text { - } & \text { Preparation and Processing } \\
\text { Improvements in } & \text { manufacture of rubber } \\
\text { - } & \text { Method and apparatus } \\
\text { - } & \text { Rubber Product } \\
\text { - } & \text { Biotechnology }\end{array}$ \\
\hline $1934-2010$ & 121 & \\
\hline
\end{tabular}

Source: Based on patent information obtained from MRB's website, www.lgm.org.my

Among the technologies developed include RRIM 900 clone series that produce high yields of natural rubber latex and produce high quality rubber-wood for making furniture, developed better latex-harvesting technology, innovated new planting methods, developed disease resistant rubber clones, and reduced the maturity period of the crop from 96 months to 54 months [9], [10]. The most significant achievement has been in developing new rubber varieties or clones. High-yielding trees producing more than 3,500 per kg per hectare and disease-resistant clones have been developed by RRIM. In addition, remarkable progress has been achieved in reducing the immaturity period from 96 to 54 months. MRB has developed new clones and technologies which will improve yield and production as well ensure better returns from rubber cultivation. Among the cultivars that have been developed by MRB are RR1M 3001, RR1M 2025, RR1M 2023, RR1M 928, RR1M 929 and PB 350. These six plant cultivars are created either to suit certain soil and vegetation conditions, or higher yield of latex or for timber purposes. 
Plantations throughout the country as well as in other rubber producing nations have adopted agro-management practice developed by RRIM. Work on soil conservation and soil fertility has helped to restore ecological balance and greening of barren land including enriching the soil. It also started venturing into improving the quality of natural rubber in particular its allergenic effect. In 2003, it filed 3 patents related to allergenic protein and 3 patents in 2004. In 2005 and 2006, it filed one patent each for allergenic protein. During this period, we can see that MRB has started exploring into research on modified natural rubber which produced 3 patents between 2004 and 2007. Its technologies include improvements of rubber lattices as well.

MRB assisted planters to shift into mechanization by developing devices and methods to ease and improve rubber tapping and processing. The first invention was in 1960 where RRIM created a device to measure gel strength and viscosity. Technology development in methods and apparatus was slow in 1970s and 1980s with only two patents registered, i.e. method and apparatus for applying a gas or vapour to a tree and rubber tapping instrument. In the $1990 \mathrm{~s}$ and 2000 s, research on mechanization or rubber production and collection received more attention, with 14 patents being granted during this period. Among the technologies include the Low Intensity Tapping System (LITS), a device created by RRIM to solve labour shortage problem in Malaysian rubber plantations. The LIT Systems consist of three technologies, i.e. LIT d/6; RRIMFLOW and REACTORRIM.

The MRB introduced high quality timber latex clones such as the RRIM 900 series, RRIM 2000 series and the latest RRIM 3000 series that resulted in bigger size trunks suitable for timber production. The contribution of rubberwood technologies to the furniture industry has been enormous where about $80 \%$ of the local furniture content are derived from rubber wood products and has generated RM7 billion exports revenue in 2009.

Another milestone of MRB is the introduction of revolutionary grading and presentation method for natural rubber through Standard Malaysian Rubber (SMR) scheme, which later became an international benchmark for the quality and properties of natural rubber [11].

MRB began to venture into genetic engineering only in the 1990s. In year 2000, it filed a patent over recombinant microorganism expressing small rubber particle-associated protein. However, the biotechnology research is still at the proof concept stage. The effort taken includes exploring the possibilities of introducing foreign genes into the Hevea genome which is known as recombinant protein. This technology is still in the lab testing stage. MRB however has initiated a few field experiments in genetic engineering by planting selected transgenic plants in isolated areas, known as "confined field trial". MRB's genetic engineering research aims for the following:

- To generate high valued proteins in the latex of the Hevea tree by inserting foreign genes.

- To improve the physiology traits of the Hevea tree e.g. disease resistance, size of the tree.

The MRB also has spearheaded green consumerism initiatives for rubber products and ventured into research in nanotechnology and advanced materials for the benefit of the industry and society [11].The latest technologies that have been introduced are Ekoprena, a speciality rubber material for 'green tyre' production, and Pureprena, an advanced rubber for engineering and eco-efficient applications. These innovations intended to further enhance the value of NR by improving the physical properties and pushing for more advanced applications [11].

In the downstream sector, the MRB introduced seismic bearing that has been proven effective for the protection of structures from earthquake damages. The bearings which were developed through collaboration with the University of California are also patent free and widely used not only in Malaysia but also in US, Japan, China, Taiwan, New Zealand and Italy [10]. In the area of marine, one useful product developed by MRB is the rubber shock cells which are used for the protection of oil and gas platforms. Rail pads made of rubbers were produced to reduce noise and vibrations of railways. MRB is also involved in the production of rubber components for the automotive industry. It is the downstream area that MRB is focusing now as there is greater demand for green tyres and biodegradable automotive parts. This is also in line with the current national thrust towards higher value-added production and advanced rubber and rubber based products.

Malaysia's achievements in R\&D and innovation in rubber technologies and products refute the claim that agricultural sectors have a low degree of technological development and have few linkages with the economy. It is important to acknowledge that the key to resource-led industrialisation and economic growth lies not only in the accumulation of knowledge but also lies in the availability of supporting facilities, good infrastructure and quality of governance [12]. This is evident in Malaysia where the government provided sufficient incentives in creating and strengthening value chain and gave continuous support in the development of human capital and knowledge enhancement in both IHLs and GRIs. In the case of rubber industry, in addition to the practice of open science by MRB especially in the upstream and midstream technologies, commendable degree of coordination between government bodies and the private sector has been the core factor in spearheading the rubber industry.

\section{REFERENCES}

[1] J. Payumo, H. Grimes, and K. Jones, "How agricultural biotechnology scientists perceive intellectual property rights (IPRs) and their implications: Insight from developing countries," International Journal of Intellectual Property Management, vol. 4, no. 4, pp. 220-238, 2011.

[2] P. Zuñiga, "The state of patenting at research institutions in developing countries: Policy approaches and practices," WIPO Economics Research Working Papers, World Intellectual Property Organization, 2011.

[3] S. A. S. Alwi, "Public sector agricultural R\&D and technology management: An assessment on mechanism and structures," Economic and Management Review, vol. 1, no. 1, pp. 29-36, 2006

[4] G. J. Stads, A. Tawang, and N. M. Beintema, "Agricultural Science and Technology Indicators (ASTI),” Country Brief, no. 30, 2005.

[5] W. Janssen, "Alternative funding mechanisms: How changes in the public sector affect agricultural research," in S. R. Tabor, W. Janssen and H. Bruneau (eds.), International service for national agricultural research, International Service for National Agricultural Research, ISNAR: the Hague, 1998.

[6] R. R. Nelson, "The advance of technology and the scientific commons," The Royal Society, vol. 361, pp. 1691-1708, 2003. 
[7] A. R. Zaharah, "Agricultural research and development in Malaysia," J. ISSAAS, vol. 18, no. 2, pp. 22-33, 2012.

[8] New Strait Times, Time to up the ante as IRRDB turns 50, 21 June 2010

[9] MRB, Milestone of Malaysian NR. (2013). [Online]. Available: http://www.lgm.gov.my.

[10] MASTIC, Ministry of Science, Technology and Innovation Malaysia. (January 2008). Insights@Mastic, vol. 6, pp. 10-11. [Online]. Available:

http://www.mastic.gov.my/documents/10156/746ea961-e520-4ab3-ab 0d-4ecda21c7af6.

[11] Rubber Asia, Malaysia will be global centre of excellence for rubber, 2009.

[12] D. Lederman and W. F. Maloney, Natural resources: neither curse nor destiny, World Bank Publication: Stanford University Press, 2007.

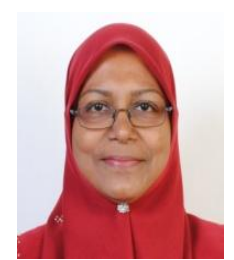

Rokiah Alavi received her Bachelor of Economics from University of Malaya in 1986 and obtained MA in Development Economics (1987) and PhD (1994) from University of East Anglia, England. Her Ph.D. thesis was on Import Substitution Industrialisation and Infant Industry Performance in Malaysia. She is currently a Professor at the Department of Economics, International Islamic University.

Her research interests are in the area of WTO, international trade and development economics. She had published a few books and wrote many articles in international and local journals. Rokiah Alavi is actively involved in training government officials and conducting short courses on economics and international trade, locally and internationally.

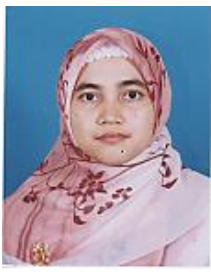

Ida Madieha bt. Abdul Ghani Azmi graduated from IIUM in 1989. After being called to the Bar in 1990, she proceeded with her LLM at the University of Cambridge (1991), thereafter completing her Ph.D. in London (1995). She wrote a thesis on IP Laws and Islam in Malaysia under the supervision of Prof Alison Firth of QMW London and Prof Ian Edge of SOAS She has undergone several fellowship programs; Max Planck International Institute of Copyright and Industrial Property Law (1995, 2005) Fulbright Master Scholar Program (1999) and Commonwealth Trust (2005). She was the visiting academic scholar for University of Nottingham (Nov 2006) and University of Monash (June 2012).

An active writer, Dr. Ida has authored three case books; Copyright: Cases and Commentary, Trade Mark: Cases and Commentary and Patents: Cases and Commentary published by Sweet \& Maxwell Asia and the co author of 5 more books. She has written more than 50 articles on various issues on Intellectual Property and Cyberlaw and presented more than 50 papers in local and international conference. She has recently completed the second edition of the Copyright Casebook to be published by end of the year.

She is currently a Professor at the Ahmad Ibrahim Kulliyyah of Laws. 